\title{
Investigation into energy performance of a school building in a hot climate: Optimum of window-to-wall ratio
}

Indoor and Built Environment 0(0) 1-16

(C) The Author(s) 2019

Article reuse guidelines:

sagepub.com/journals-

permissions

DOI: $10.1177 / 1420326 \times 19842313$ journals.sagepub.com/home/ibe

@SAGE

\author{
Mamdooh Alwetaishi ${ }^{1}$ (I) and Ahmad Taki ${ }^{2}$
}

\begin{abstract}
Global attention is currently focussed on developing techniques to improve the thermal performance of buildings to provide indoor comfort with minimum reliance on energy load. Several studies have investigated building facade, materials used and other factors involved in building design. The aim of this study is to examine the impact of thermal insulation, shading devices, window-to-wall ratio (WWR) and a combination of these factors in a prototype school building design in the warm climate city of Taif, Saudi Arabia. The study used various methods classified into two main phases. The first phase involved on-site observation where both thermal imaging and regular cameras were used to examine the influence of orientation on glazing as a baseline. The second phase involved advanced software investigations with 2D AutoCAD, 3D Revit and computer modelling for energy evaluation and daylight factor. A detailed framework was introduced to examine current school buildings and to improve the future designs of prototype school buildings. The study revealed that a combination of applying thermal insulation along with minimising WWR is required in existing buildings within hot and dry regions. Furthermore, it was recommended that WWR should not exceed $35 \%, 25 \%$ and $20 \%$ for northwest, southeast and southwest building facades, respectively.
\end{abstract}

\section{Keywords}

School buildings, Thermal insulation, Window-to-wall ratio, Energy efficiency, Daylight factor, Hot climate

Accepted: 16 March 2019

\section{Introduction}

Buildings should be designed with their microclimate conditions considered. This ensures high energy performance with minimum reliance on energy loads. The kingdom of Saudi Arabia announced and established 'Vision 2030' in 2016 ${ }^{1}$ aimed at improving the performance of buildings associated with occupant discomfort. In order to ensure a significant impact, only existing buildings were considered as they consume significantly greater energy than new buildings. With respect to schools in Saudi Arabia, there was an educational boom from 1975 to 1985 due to increases in student enrolment as well as rapid increases in oil production. The government provided full support to the education sector, and several programmes were announced such as the education plan in 1970 and public private partnership (PPP) planning for the purpose of school building development across the kingdom. Over the past 40 years, the number of students enrolled has increased from 300,000 to five million in 2004. Additionally, the number of schools has increased from 3283 in 1970 to 30,414 in $2004 .^{2}$ Thus, there was a rapid increase in school building demands to satisfy the needs of the nation. Figure 1

\footnotetext{
${ }^{1}$ Department of Civil Engineering, Faculty of Engineering, Taif University, Taif, Saudi Arabia

${ }^{2}$ Leicester School of Architecture, De Montfort University, Leicester, UK
}

\section{Corresponding author:}

Mamdooh Alwetaishi, Department of Civil Engineering, College of Engineering, Taif University, BOX. 888, Taif City 21974, Saudi Arabia.

Email: m.alwetaishi@tu.edu.sa 


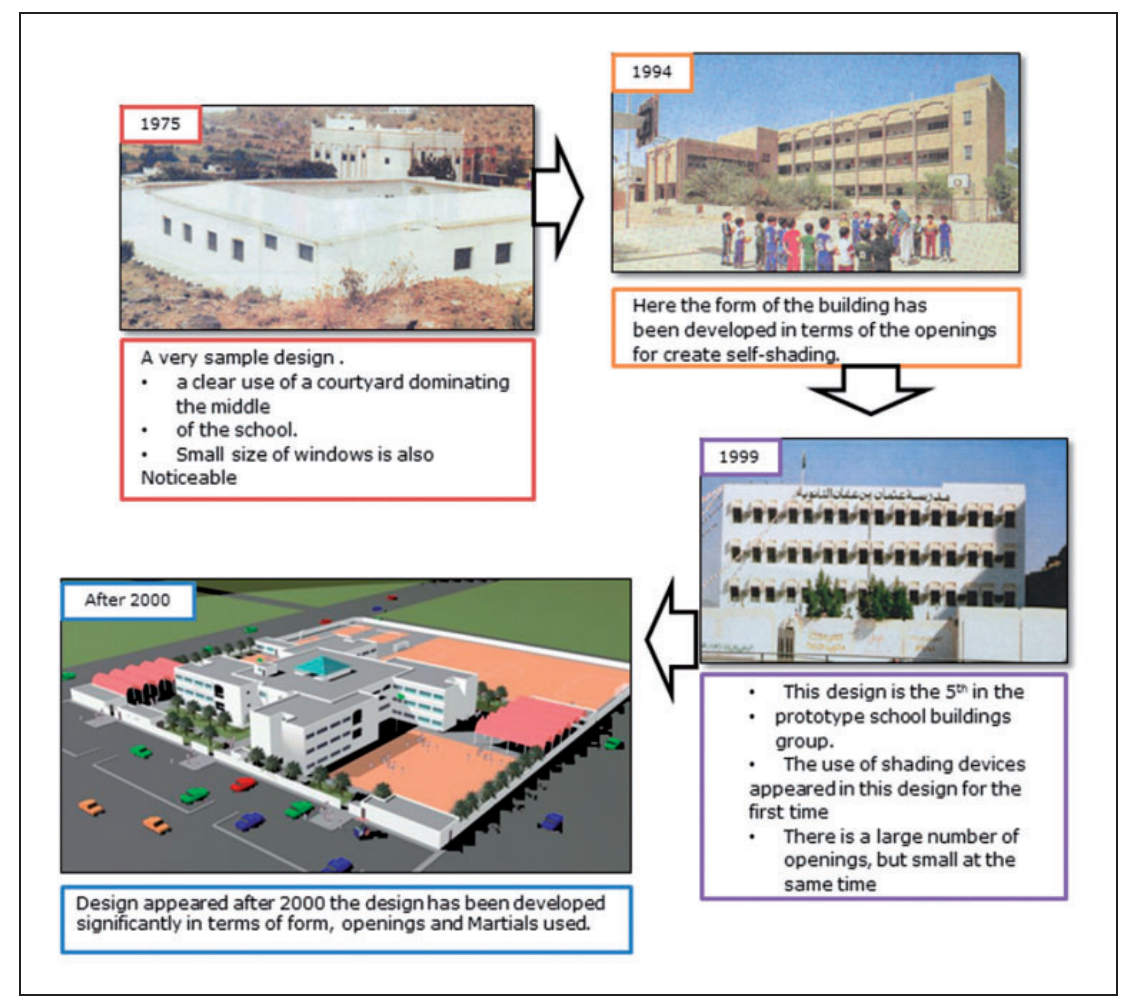

Figure 1. Prototype development of school building in Saudi Arabia over the past 50 years. ${ }^{3}$

displays the rapid improvement in the design of school buildings in Saudi Arabia over the past 50 years.

Thermal insulation is a key strategy for efficient buildings, ${ }^{4-11}$ especially in extreme climates where outdoor temperatures vary widely. Material density is strongly linked to its thermal conductivity, ${ }^{12}$ and increases in insulation leads to a decrease in thermal conductivity (k-value). Thermal insulation is used in various climatic regions across the world with specific focus on its influence on energy loads. ${ }^{11}$ However, the reductions in energy loads are associated with the thickness of the thermal insulation. ${ }^{13}$ Thermal insulation thickness cannot be selected arbitrarily as it affects the cost of building construction. ${ }^{8}$ Thus, there should be an optimum thickness wherein the cost and performance are acceptable. In warm regions, such as those in the present study, the optimum orientation thicknesses of the thermal insulations corresponded to 3.6 $\mathrm{cm}, 3.1 \mathrm{~cm}, 4 \mathrm{~cm}$ and $4 \mathrm{~cm}$ in the south, north, east and west directions, respectively. ${ }^{14}$ Furthermore, the study revealed that external thermal insulation was more beneficial than applying it to the middle of the external wall. This aided in controlling moisture and thermal bridges, and also the use of thermal mass techniques. This supports the strategy in the current study wherein thermal insulation is applied on the outer surfaces of the existing schools. Other studies suggest that it is difficult to apply this strategy due to the increased costs with insulation of higher floors. ${ }^{6}$ Nevertheless, some studies contradict this. For example, it was found that thermal insulation within the inner surface was better for ensuring energy performance. ${ }^{15}$ For the climate of Saudi Arabia, the optimum thickness of thermal insulation applied to the outer surface of an external wall was in the range of 5 to $10 \mathrm{~cm} .{ }^{15}$ Another study supported this. Saleh ${ }^{16}$ investigated the impact of insulation configuration on the annual cooling load in the city of Riyadh. He found that outer application of insulation was more beneficial than inner insulation, and for intermittent cooling operations. ${ }^{17,18}$ Thermal insulation was more efficient when it was applied into internal cavities of external walls. As such, it can be observed that in intermittent cooling regions, internal thermal insulation is more preferable, while in continuous cooling operation external thermal insulation is more effective.

Alwetaishi ${ }^{19}$ investigated the influence of windowto-wall ratio (WWR) in various climatic regions in Saudi Arabia. The results indicated that WWR in hot dry or hot humid climates should not exceed $10 \%$ in all directions due to the harshness of the climate, while the WWR ranges can be as high as $20 \%$ in moderate climates. A study in a similar climate in Libya ${ }^{20}$ examined the impact of WWR in cold and hot periods. The study highlighted that the influence of increasing WWR on the southern side caused increases in the cooling load in 
summer and nearly zero loads of heating in winter. Thus, each direction should exhibit various WWRs based on the local climate. Irrespective of the climate, WWR should be fully considered as it affects the energy loads in both cold and hot regions. A study ${ }^{21}$ indicated that a single-glazed window exhibited a greater impact on the energy load than any other element in a building, while low-emissivity or hollow glass windows can significantly improve the life-cycle energy performance. Furthermore, WWR should be fully considered as it also affects the total energy load even in cold climates. ${ }^{22,23}$

This study focuses on the energy performance of a school building and especially on energy loads, building envelope, and WWR in hot and dry climates. The study used different methods to enhance the framework and findings. On-site observations were conducted via a thermal imaging camera with grid infrared temperature measurements. Additionally, TAS Environmental Design Solutions Limited (EDSL) was used to predict the energy loads in the school. This is well-known software that has been used in several studies in various countries, including Saudi Arabia, ${ }^{24}$ Singapore, ${ }^{25}$ Austria, ${ }^{26}$ Italy, ${ }^{27,28}$ Chile, ${ }^{29}$ Poland, ${ }^{30}$ United Kingdom ${ }^{31,32}$ and Turkey. ${ }^{33}$ The main aim of the study was to produce a guideline for the Ministry of Education to improve current and future school buildings.

\section{Local climate condition and context of case study}

The climate of Taif City is considered as hot and dry. The hot climate in summer in the city is as harsh as other parts of the kingdom of Saudi Arabia. It exhibits an average temperature in mid-30s during day time and a cold climate during winter time. Furthermore, it has a considerably warm to moderate climate in both spring and autumn (Figure 2). The local climate arises due to the high mountainous location of the city, which lies on Hada Mountain at $1700 \mathrm{~m}$ above sea level. The city elevation increases further south and west and decreases to the east and north. With respect to the cultural context of Saudi Arabia, individuals prefer using air conditioning irrespective of the microclimate condition of the city. A few individuals prefer to not use it in work places and offices. However, given the high amount of occupant heat gain in classrooms, the need for air conditioning systems is significant, especially in the summer.

\section{Problem description}

School buildings in the kingdom of Saudi Arabia are in the form of prototype school building designs (PSBD)

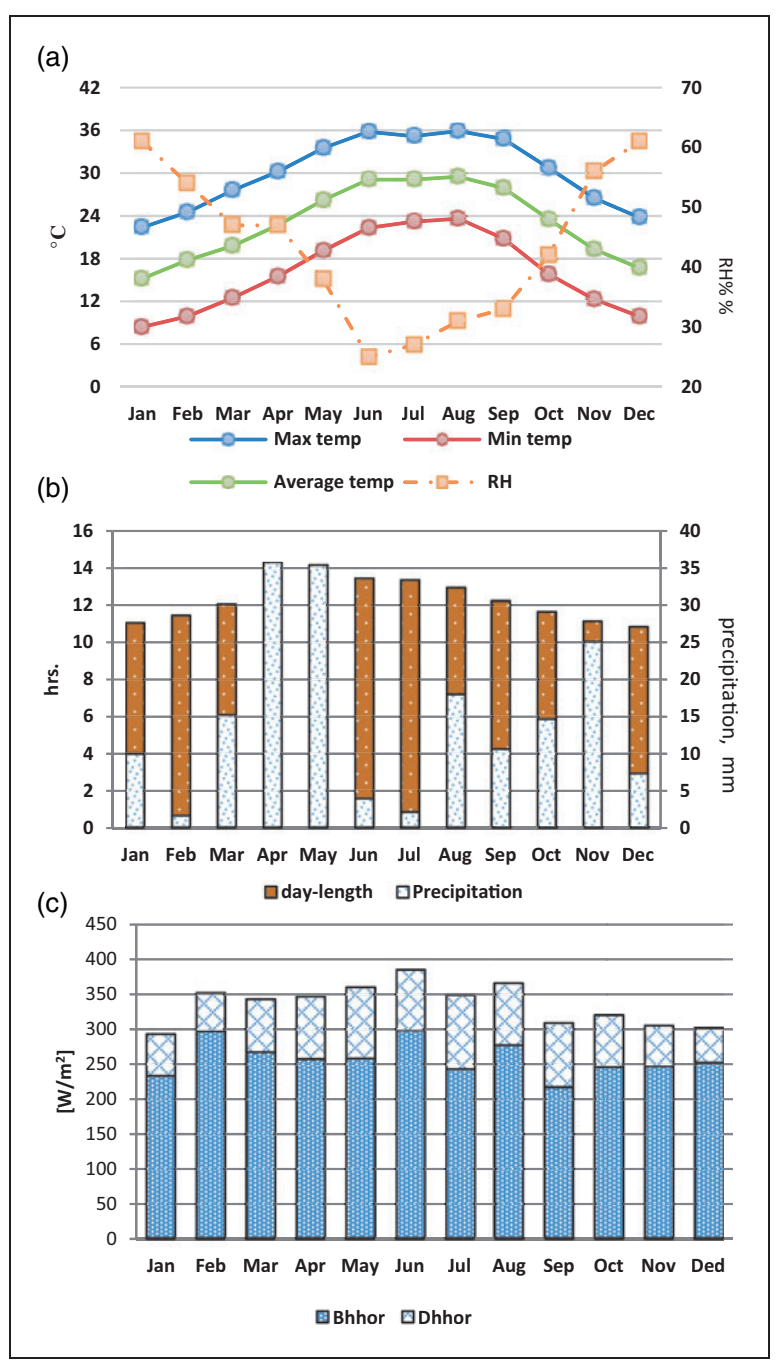

Figure 2. Climate of Taif City, reproduced from the epw file derived from the Meteonorm $\operatorname{site}^{34}$ : (a) fluctuations of outdoor temperature and relative humidity; (b) day length and precipitation; (c) direct and diffused radiation, where Bhhor is mean irradiance of beam with high horizon, and Dhhor is the mean irradiance of diffuse radiation horizontal with high horizon.

of the late 19th century (Figure 1). The same design is repeated in all cities and towns across the region, irrespective of the local climatic condition. Thus, any errors in the design stage are significant due to the large number of school buildings. In the first group of PSBD, there are 14 schools, and none of them have given attention towards sustainable design features, such as orientation, optimal glazing ratio, use of thermal insulation and shading devices. One of most important and widespread designs corresponds to the case study of this research. This was selected because it is the most popular school building design in the kingdom. The aim of this study was to provide a validated framework for the Ministry to improve 
future PSBD in Saudi Arabia. Furthermore, in the short term, the study aimed to propose a framework that can be implemented in current schools to improve their energy performances because focusing only on new schools will not significantly impact the actual energy consumption in the educational sector. A very limited extant study examined school buildings in the kingdom by considering other prototypes such as design numbers 11 and 14 which are considered as latest designed schools in Saudi Arabia Figure 1, for instance, shows design number 11 which appeared after the year of 2000, in comparison with traditional schools in various climatic regions., ${ }^{2,35}$

\section{Case study and site observations}

The school was designed with single cavity walls and includes elementary, intermediate and high school classes. However, it is usually only used for one class level (perspectives shown in Figure 3). The version of the school is considerably old and includes new architectural drawings from the ministry of education. Thus, a contribution of the study involves re-producing all the architectural and surveying drawings (Figure 4). The school was visited to determine the base case condition. This included obtaining photos of students while wearing different clothing items (Figure 5) and obtaining actual/thermal images of the glazing (Figure 6).

The school was visited several times in the winter of 2017, between 8 and 22 January, to obtain measurements for architectural drawings, and to determine the level of glazing at different orientations. It was conducted on a daily basis from 8 am to $4 \mathrm{pm}$. Figure 6 shows that southwest glazing in classroom number 2 exceeded $50^{\circ} \mathrm{C}$ at 8 am, due to the incidence of direct solar radiation. Furthermore, the users of the school reacted by covering the inner surface of the classroom with black sheets to attempt to block the sunlight and reduce the glare. However, black colour sheets absorbed heat and thus the situation was worsened. Conversely, it was observed from measurements (Figure 6) that a northwest facing classroom exhibited a maximum of $32.5^{\circ} \mathrm{C}$, at the same time and indicating the effect of orientation. These measurements included dry bulb temperatures, relative humidities and surface temperatures (Figure 7). All classrooms should be treated by a suitable shading technique considering the orientation. Taif City is located in the mountains of Saudi Arabia and exhibits a cool climate in winter and a hot climate in summer. However, high solar radiation affects the area. Thus, an appropriate WWR should be applied to the school. Alwetaishi ${ }^{19}$ highlighted that WWR should not exceed $20 \%$ in all directions in a moderate climate to reduce heat loss and gain in the building. In the school, WWR was significantly high at $20 \%$. Two main treatments were applied to affect the building design after the completion of construction. The first one involved controlling direct sunlight with either internal or external shades, and the other involved minimising the area of glazing via shutters to obtain a $50 \%$ reduction in WWR. Black sheets should be banned in all schools in Saudi as this phenomenon was noticed in other schools based on previous studies. ${ }^{24}$ Both treatments did not affect daylight as the amount of solar radiation was extremely high at the base study location.

\section{Methodology}

The major method used in the study was the energy performance tool known as TAS EDSL (Table 1 presents a description of all tools and equipment used in the study). The software was used with the school model twice. The first use was for a free-running building (Baseline case) in order to study the existing performance of the school (Figure 8) while the second use was to determine the energy consumption of classrooms based on internal conditions of temperature between $19^{\circ} \mathrm{C}$ and $24^{\circ} \mathrm{C}$. The study was not limited to software packages (Figure 7 shows the flow of the study). The methodology of the study was divided into three main stages.

- The first stage was related to site observation where normal and thermal cameras were used to

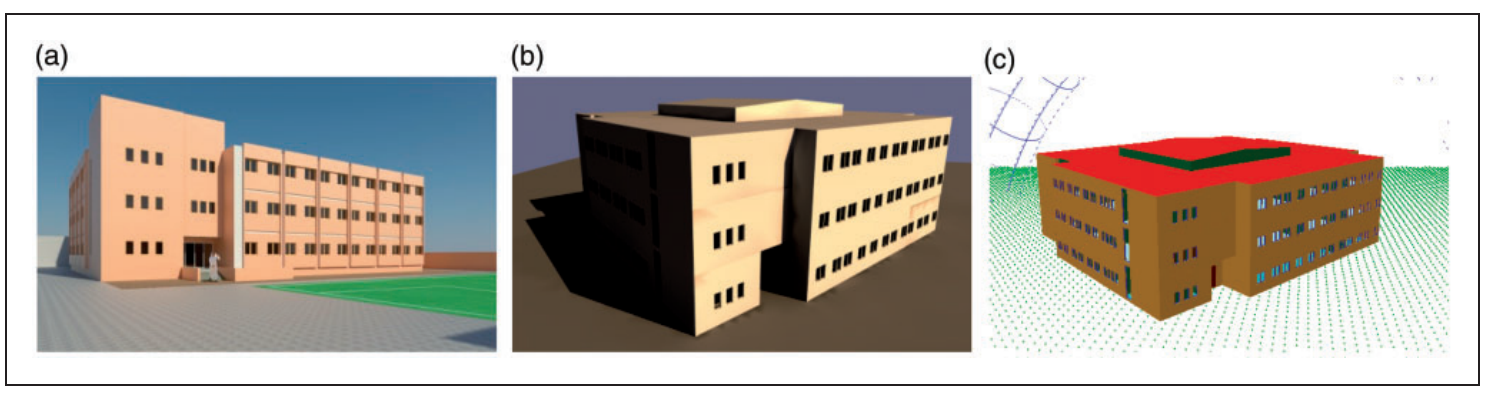

Figure 3. Perspectives of the school: (a) perspective from Revit Autodesk; (b) rendered TAS 3D image taken from daylight viewer with actual shading on 21 June at 4 pm; (c) typical TAS 3D Modeller. 


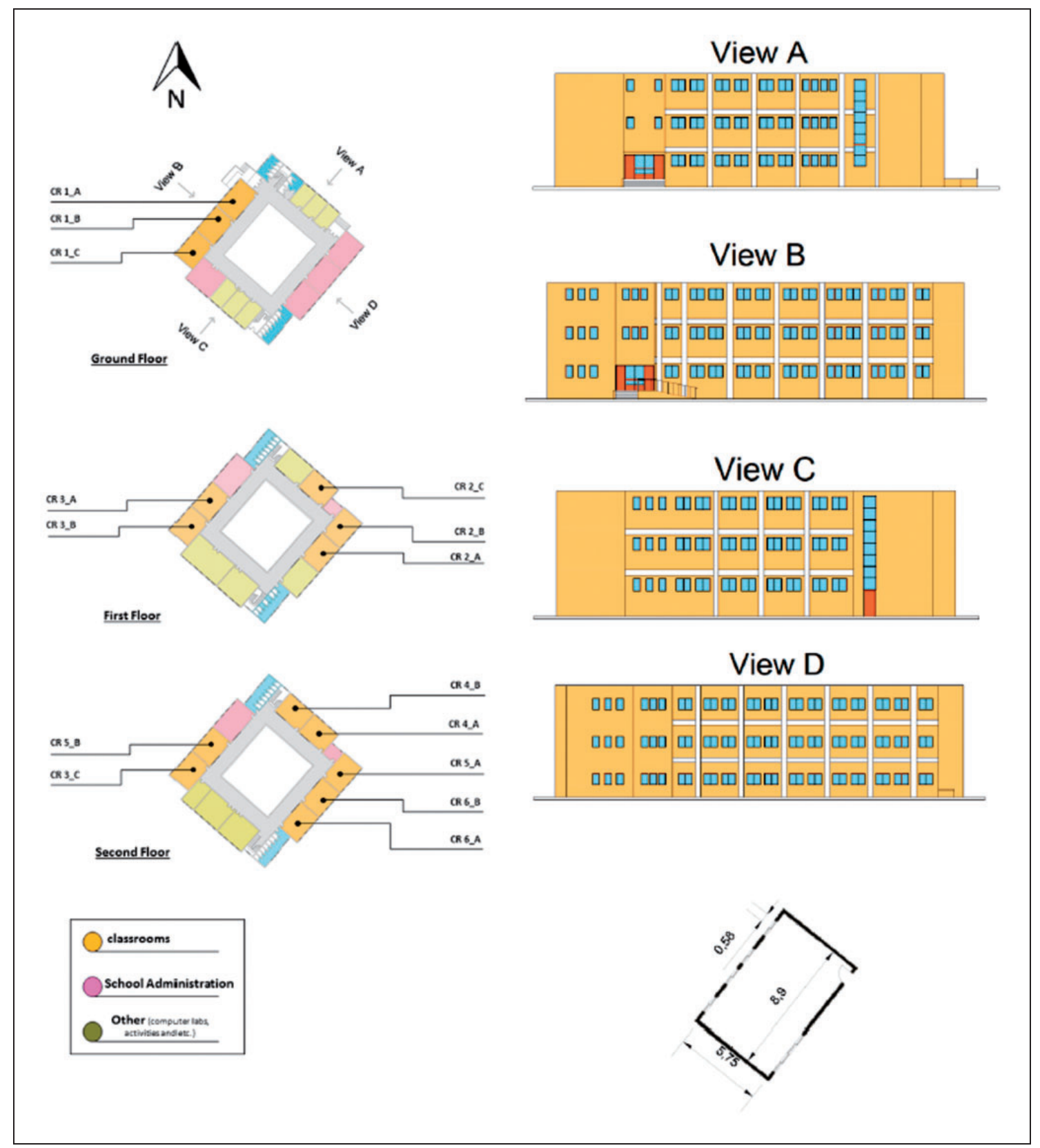

Figure 4. Architectural drawings of the case study with detailed dimensions (m) of a prototype classroom.

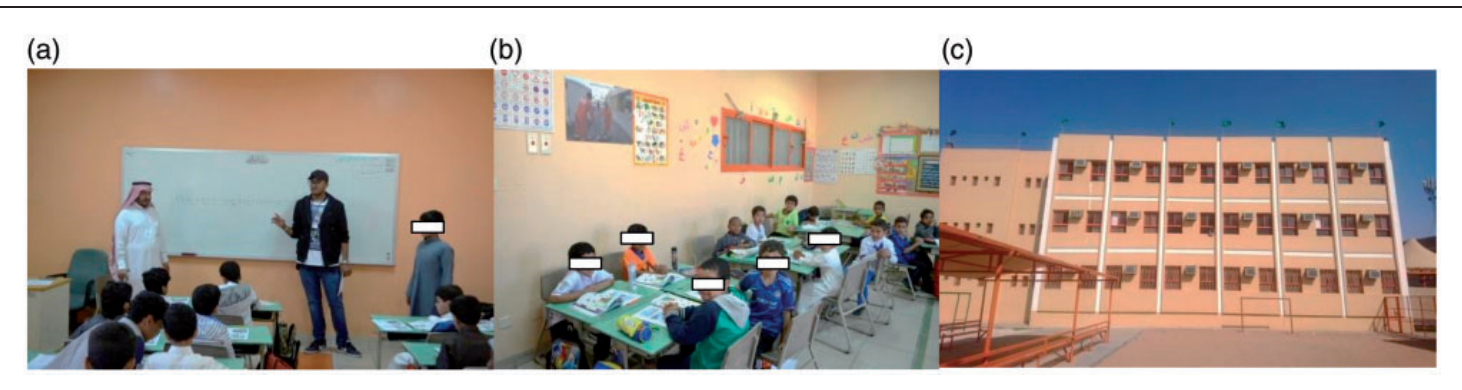

Figure 5. Site observations of the school: (a) the research team explaining the visit and measurement, (b) a view of one of the classrooms, and (c) the northeast orientation of the school. 


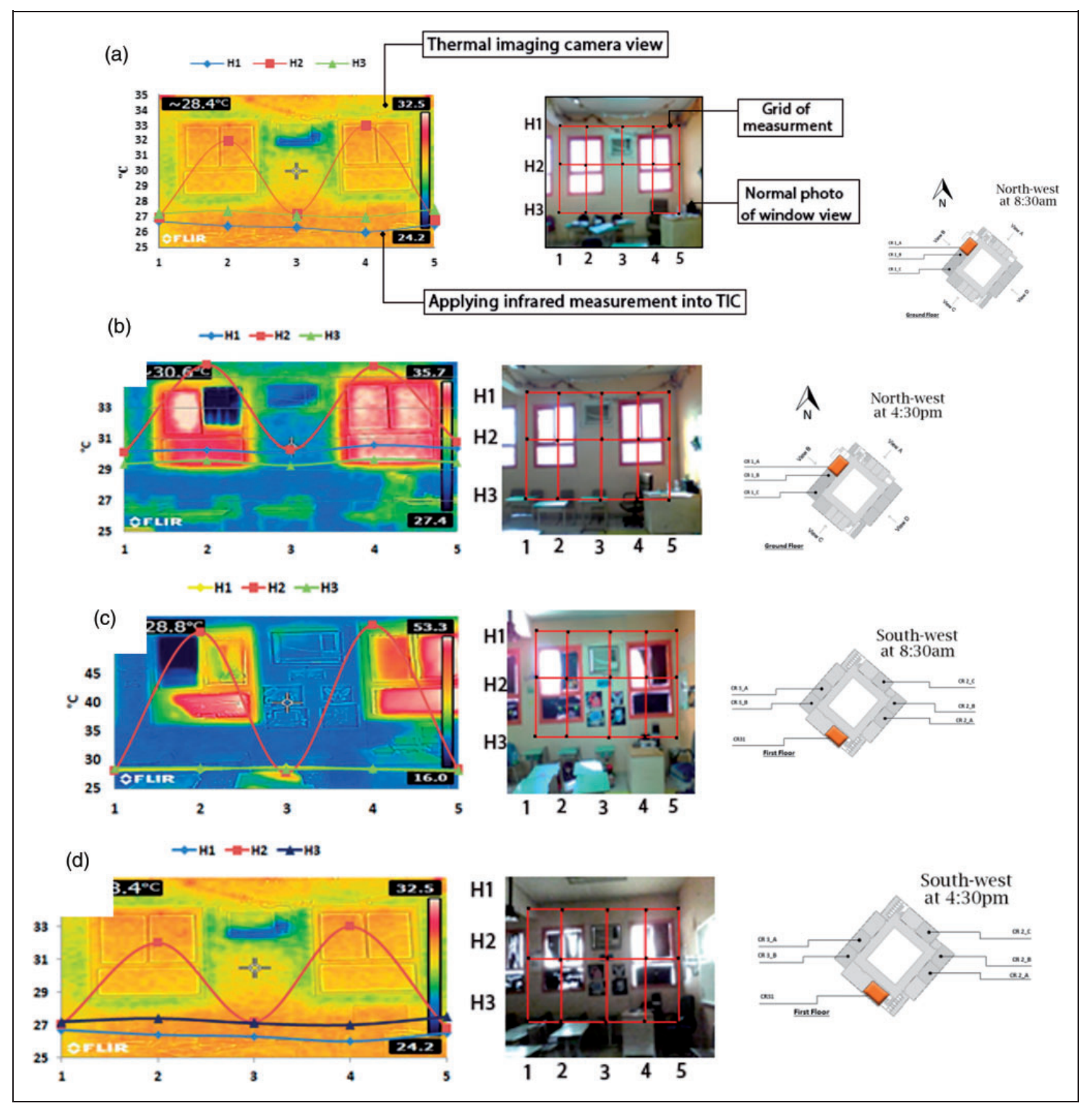

Figure 6. Glazing site observation using normal camera, thermal camera and infrared surface temperatures: (a) denotes classroom (CR) 1_A at 8:30 am, (b) denotes CR 1_A at 4:30 pm, (c) denotes CR_31 at 8:30 am, and (d) denotes CR_31 at 4:30 $\mathrm{pm}$ in winter.

investigate the performance of the glazing for various orientations and time intervals. Two times were selected, 8:30 am and 4:30 pm, which were the start and the end of the school day, to reflect the minimum and maximum of amount of solar radiation to the school. When using the thermal imaging camera, an infrared thermometer was also used for comparison (Figure 6).

Case study of classrooms was based on orientation and availability as not all spaces in the school were available during scheduled visits. There are three orientations with three classrooms, CL 1_A for northwest,
CL 2_A for southeast and CL 31 for southwest (Figure 6). It was not possible to pick up a single orientation due to the tilted layout of school building.

- The second stage involved using advanced modelling and energy tools to produce a daylight analysis.

- The final stage considered building modification and involved investigating three different models and techniques, which compared the baseline case with cases where thermal insulation was applied to outer surfaces or the glazing-to-wall ratio was minimised (properties used are listed in Table 3). 


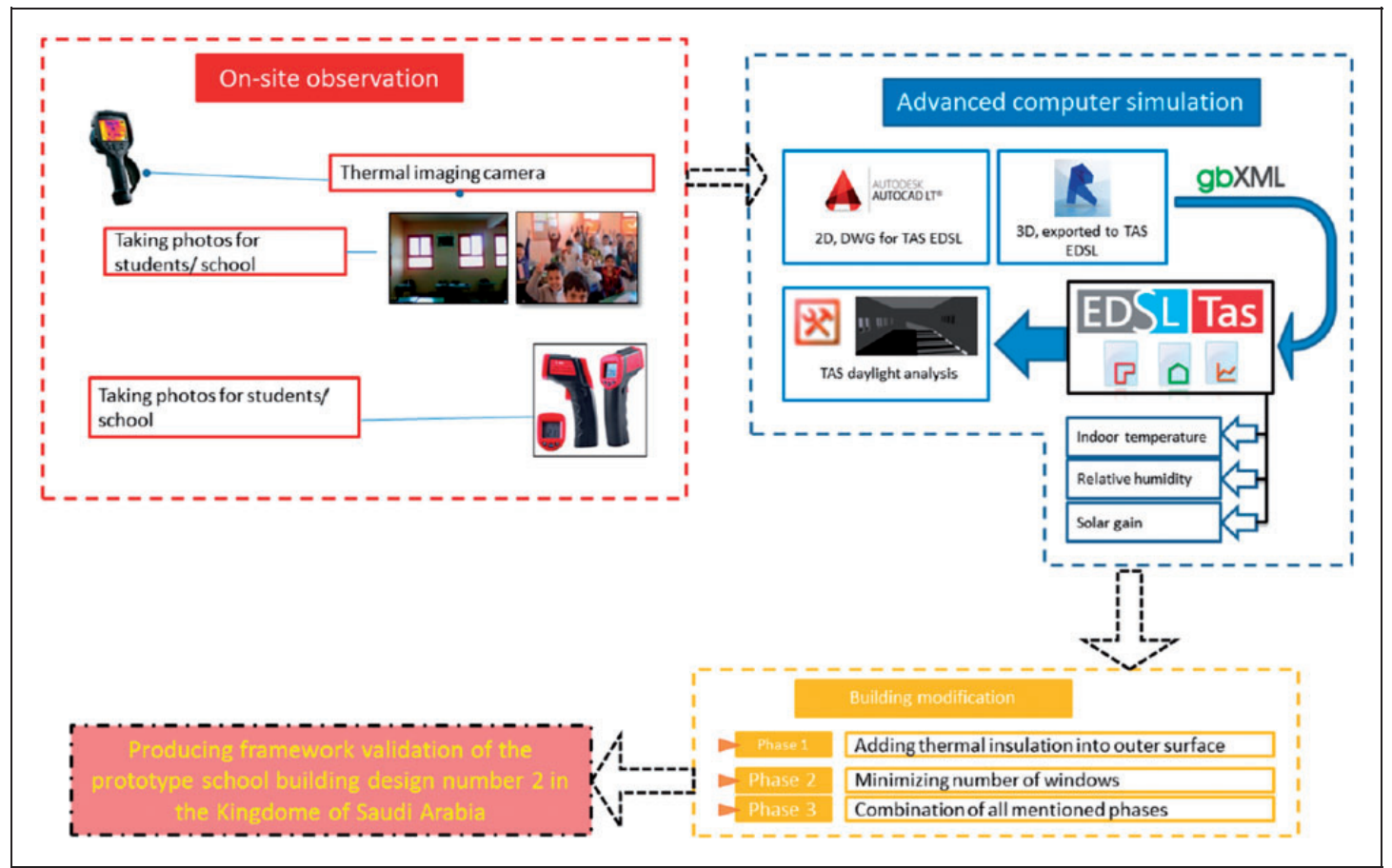

Figure 7. Flow chart of the research methodology.

Table 1. Description of tools and equipment used in the study.

\begin{tabular}{|c|c|c|c|}
\hline Tool/equipment & Manufacturer & Purpose & Country \\
\hline Infrared thermometer & $\begin{array}{l}\text { Ashby Technical } \\
\text { Products (ATP) }\end{array}$ & $\begin{array}{l}\text { To measure surface temperature at a select- } \\
\text { ed point }\end{array}$ & UK \\
\hline Thermal imaging camera & $\begin{array}{l}\text { Forward Looking Infrared } \\
\text { Radiometer (FLIR) }\end{array}$ & $\begin{array}{l}\text { To measure surface temperature distribution } \\
\text { by colours }\end{array}$ & USA \\
\hline AutoCAD & Autodesk & $\begin{array}{l}\text { Creating } 2 \mathrm{D} \text { files to be exported by DWG into } \\
\text { TAS EDSL }\end{array}$ & USA \\
\hline Revit & Autodesk & $\begin{array}{l}\text { Creating } 3 \mathrm{D} \text { files to be exported by gbXML } \\
\text { into TAS EDSL }\end{array}$ & USA \\
\hline TAS & EDSL & $\begin{array}{l}\text { For building energy simulation and } \\
\text { day lighting }\end{array}$ & UK \\
\hline
\end{tabular}

\section{Results and discussion}

The importance of this study is in its provision of a framework for the Ministry of Education in the region; to determine the framework on usage of thermal insulation and appropriate selection of WWR and orientation. Cooling load is a key consideration in climate-responsive buildings. With the aid of improved building fabrication, a reduction of 30 to $45 \%$ of the total energy cooling load was possible (Figures 9 and 10). Figure 10 presents cooling loads for both existing and improved building fabrication, the improved energy load is the bold/hatched bars as they can be seen in the figure. Summer saving was greater than winter saving. This was due to excessive high outdoor temperatures in summer and autumn. In addition, when insulation was used in the proposed external walls, there was a large impact on total U-value, see comparison given in Tables 2 and 3, where it dropped from 3.15 to only $0.32 \mathrm{~W} / \mathrm{m}^{2} \cdot \mathrm{K}$. Such improvement is attributed to thermal insulation, which aided external wall energy efficiency. In the southwest facing classroom (Figure 8), temperatures were surprisingly higher in autumn than in summer. This was due to the lower angle of sunlight that enabled more direct solar heat gain in this period. Figure 8 supports this 


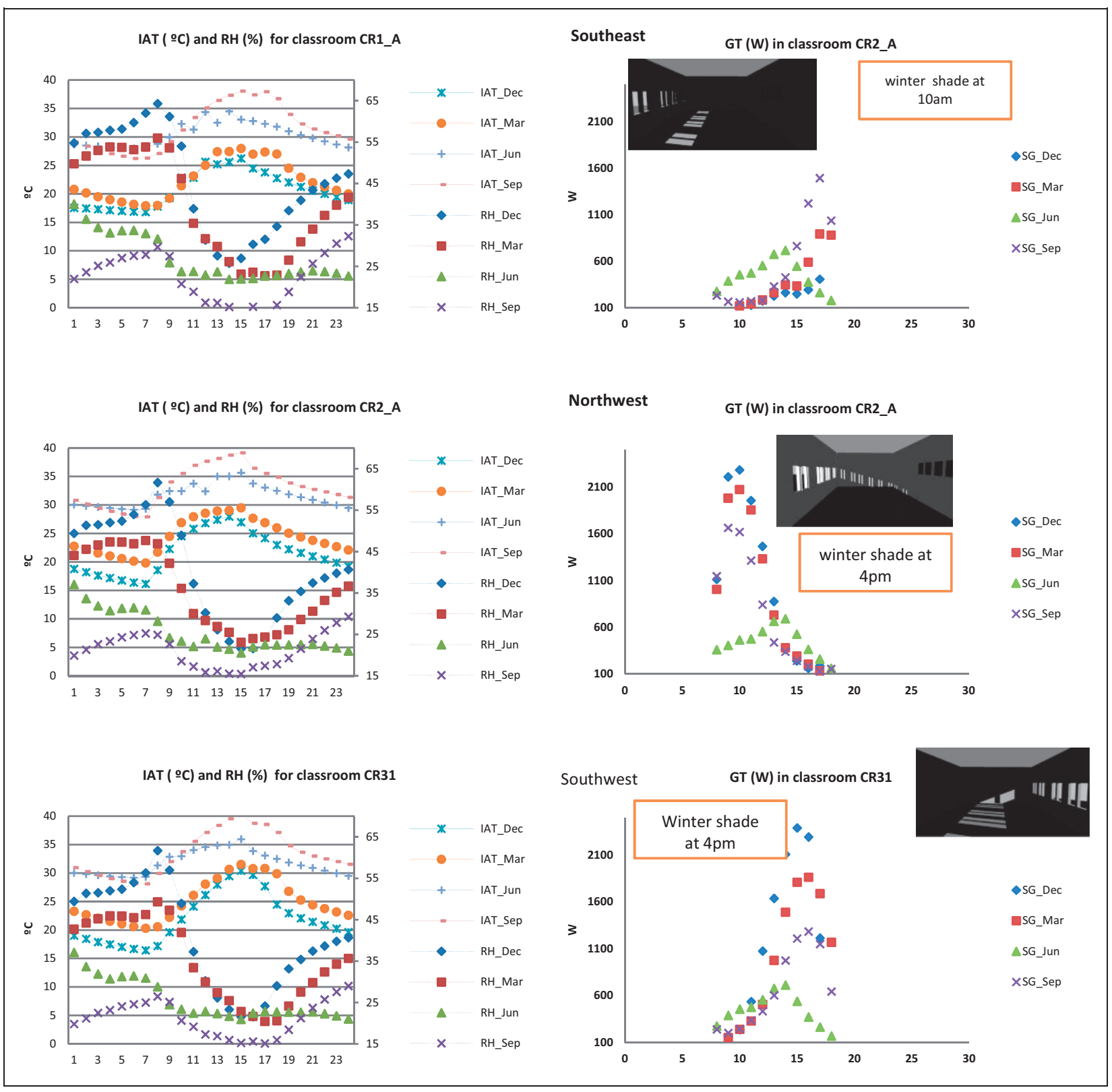

Figure 8. Indoor air temperature (IAT), relative humidity $(\mathrm{RH})$ and solar heat gain $(\mathrm{GT})$ in the classrooms for various seasons for original building (Base case) derived from TAS EDSL.

and shows the higher amount of solar heat gain in autumn, and hence this orientation should be protected by either shading devices or minimising WWR.

The main aim of the study was to determine those aspects that impact the performance of the current school building design. Also, building modifications were considered, such as applying $90 \mathrm{~mm}$ of thermal insulation to the outer surface of the external wall of the school building and minimising WWR, which was observed as fundamental (Figures 10 and 11). These modifications were selected as it is possible to apply them into existing buildings. Moreover, they have clear impact on energy saving in buildings based on previous publications. ${ }^{16,36-38}$ Several previous studies have considered applying thermal insulation on the outer surface of an external wall, ${ }^{36}$ although a few studies consider that it should be applied in the middle of the external wall. ${ }^{14}$ One study ${ }^{6}$ focused on the difficulty of applying insulation on the outer surfaces of high-rise buildings. It is easier to apply insulation either to the internal or the external wall in existing buildings. The position selected for thermal insulation within the external wall depends greatly on the climatic conditions. ${ }^{39}$ For regions with continuous cooling 


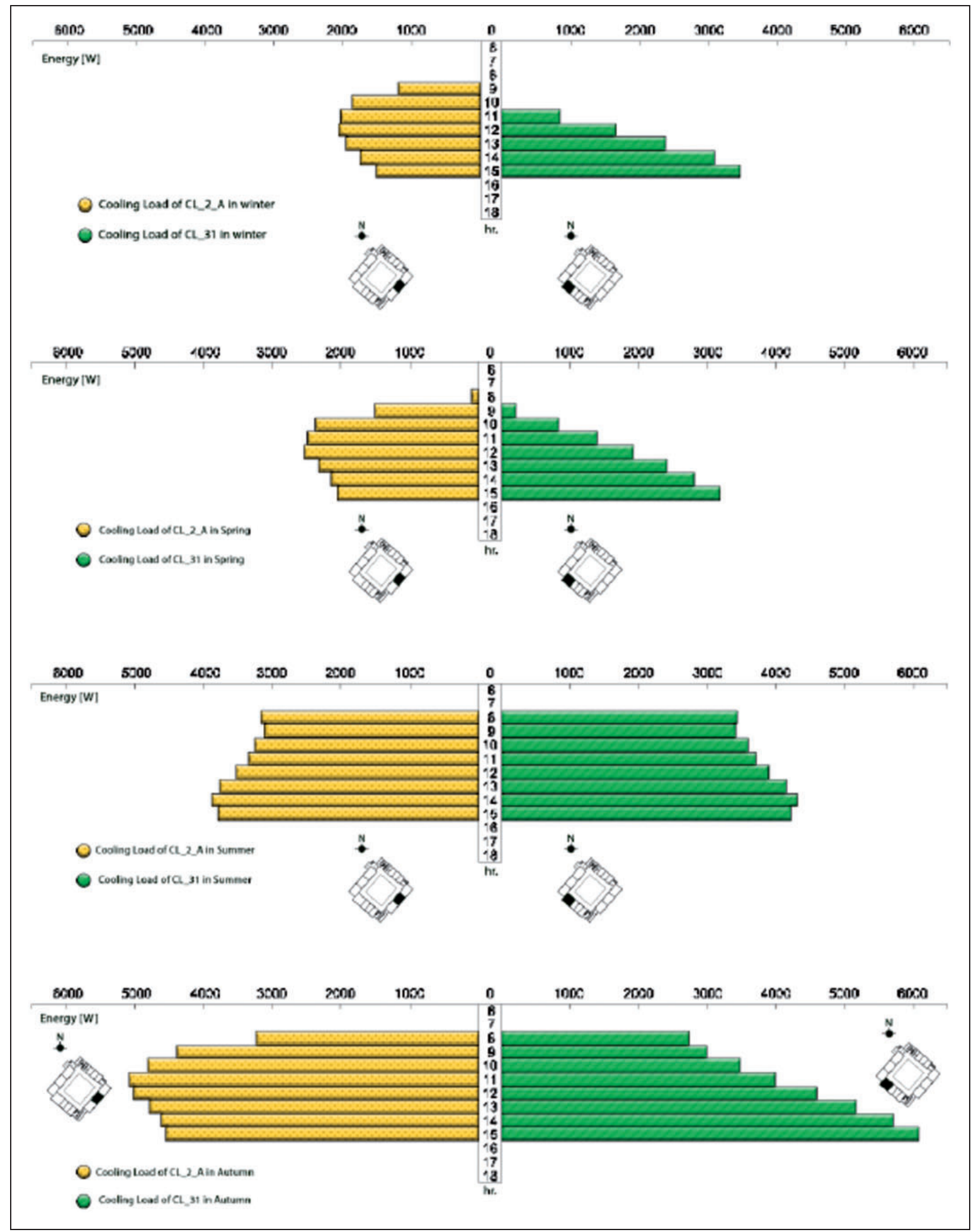

Figure 9. Current cooling loads (W) of selected classrooms in the school.

loads, external insulation is more advisable. ${ }^{16,37}$ Additionally, in the US six different climatic conditions were investigated ${ }^{38}$ and it was found that external insulation was more effective than internal. In locations where there is a need for both cooling and heating demands, ${ }^{40}$ researchers found that external insulation outperformed internal by 2 to $11 \%$. In contrast, Bojic ${ }^{13}$ who investigated the annual estimation of cooling load in high rise building in Hong Kong and found otherwise. The maximum cooling load was observed when 


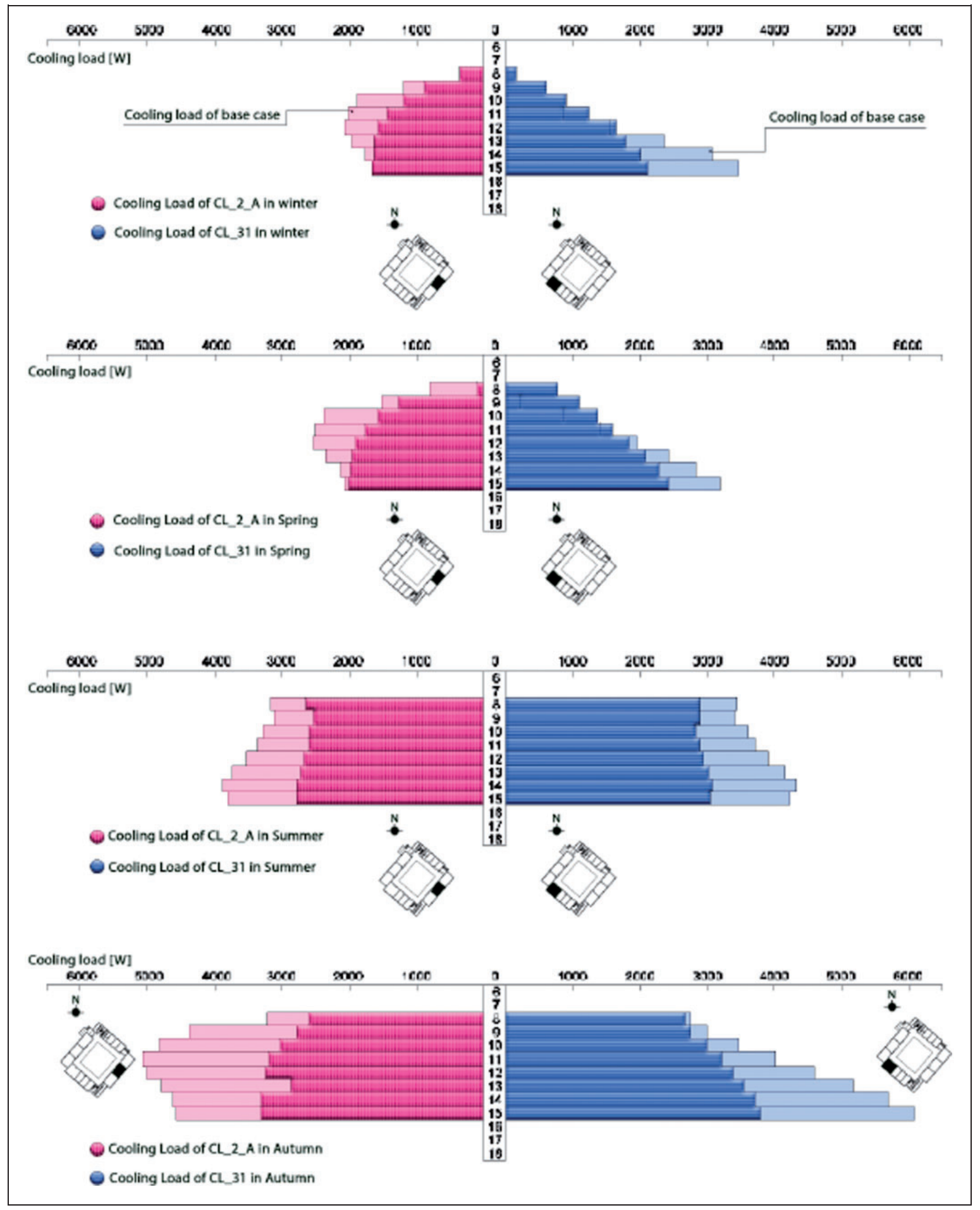

Figure 10. Improved fabrication cooling load for energy saving (W) in comparison with the base case, where the bold/ hatching bars are the improved fabrication distribution.

the thermal insulation installed on the outside of external wall, while a reduction of $6.8 \%$ was achieved when the thermal insulation installed on inside wall. Based on previous findings, the internal insulation is considered more suitable for intermittent cooling regions, while external insulation is more suitable for regions with continuous cooling. This is shown in the present study where the indoor air temperatures were almost constant and ranged from $21^{\circ} \mathrm{C}$ to $25^{\circ} \mathrm{C}$ during the day in winter and approximately $30^{\circ} \mathrm{C}$ in summer in 
Table 2. Properties of the base case model of the school.

\begin{tabular}{|c|c|c|c|c|c|c|c|}
\hline & \multicolumn{2}{|l|}{ Layers } & \multicolumn{2}{|l|}{ Width (mm) } & \multicolumn{2}{|l|}{$\begin{array}{l}\text { Conductivity } \\
(\mathrm{W} / \mathrm{mK})\end{array}$} & $\begin{array}{l}\text { Total U value } \\
\left(\mathrm{W} / \mathrm{m}^{2} \cdot \mathrm{K}\right)\end{array}$ \\
\hline External wall & Block & & 200 & & 1.31 & & 3.15 \\
\hline Internal wall & Block & & 100 & & 1.31 & & 4.0 \\
\hline \multirow{4}{*}{ Floor } & Concrete sc & ed & 50.0 & & 1.28 & & 0.316 \\
\hline & Concrete & & 125.0 & & 0.87 & & \\
\hline & Crashed bri & x aggregate & 75.0 & & 0.55 & & \\
\hline & Sand dry & & 1000.0 & & 0.32 & & \\
\hline \multirow[t]{3}{*}{ Roof } & Concrete & & 100 & & 0.3 & & 0.274 \\
\hline & Roofing fel & layer & 5.0 & & 0.41 & & \\
\hline & Grey slate & & 10.0 & & 2.0 & & \\
\hline \multicolumn{8}{|l|}{ Glazing type } \\
\hline \multirow[t]{2}{*}{ Glazing } & $\begin{array}{l}\text { Type of } \\
\text { glazing }\end{array}$ & Width $\mathrm{mm}$ & $\begin{array}{l}\text { Solar } \\
\quad \text { reflectance }\end{array}$ & $\begin{array}{l}\text { Solar } \\
\text { absorbance }\end{array}$ & $\begin{array}{l}\text { Solar } \\
\quad \text { transmittance }\end{array}$ & Emissivity & $\begin{array}{l}\text { Total U value } \\
\left(\mathrm{W} / \mathrm{m}^{2} \cdot \mathrm{K}\right)\end{array}$ \\
\hline & Single & 10.00 & 0.070 & 0.115 & 0.7 & 0.845 & 5.53 \\
\hline
\end{tabular}

Table 3. Properties of the proposed model.

\begin{tabular}{|c|c|c|c|c|c|c|c|}
\hline & \multicolumn{2}{|l|}{ Layers } & \multicolumn{2}{|c|}{ Width (mm) } & \multicolumn{2}{|l|}{$\begin{array}{l}\text { Conductivity } \\
(\mathrm{W} / \mathrm{mK})\end{array}$} & $\begin{array}{l}\text { Total U value } \\
\left(\mathrm{W} / \mathrm{m}^{2} \cdot \mathrm{K}\right)\end{array}$ \\
\hline \multirow[t]{3}{*}{ External wall } & \multicolumn{2}{|l|}{ Block } & \multicolumn{2}{|l|}{100} & \multicolumn{2}{|l|}{1.31} & \multirow[t]{3}{*}{0.32} \\
\hline & \multicolumn{2}{|l|}{ Insulation } & \multicolumn{2}{|l|}{90} & \multicolumn{2}{|l|}{0.048} & \\
\hline & \multicolumn{2}{|l|}{ Block } & \multicolumn{2}{|l|}{100} & \multicolumn{2}{|l|}{1.31} & \\
\hline \multirow{5}{*}{$\begin{array}{l}\text { Internal wall } \\
\text { Floor }\end{array}$} & \multicolumn{2}{|l|}{ Block } & \multicolumn{2}{|l|}{100} & \multicolumn{2}{|l|}{1.31} & 4.0 \\
\hline & \multicolumn{2}{|c|}{ Concrete screed } & \multicolumn{2}{|l|}{50.0} & \multicolumn{2}{|l|}{1.28} & 0.316 \\
\hline & \multicolumn{2}{|c|}{ Concrete } & \multicolumn{2}{|l|}{125.0} & \multicolumn{2}{|l|}{0.87} & \\
\hline & \multicolumn{2}{|c|}{ Crashed brick aggregate } & \multicolumn{2}{|l|}{75.0} & \multicolumn{2}{|l|}{0.55} & \\
\hline & \multicolumn{2}{|c|}{ Sand dry } & \multicolumn{2}{|l|}{1000.0} & \multicolumn{2}{|l|}{0.32} & \\
\hline \multirow[t]{3}{*}{ Roof } & \multirow{3}{*}{\multicolumn{2}{|c|}{$\begin{array}{l}\text { Concrete } \\
\text { Roofing felt layer } \\
\text { Grey slate }\end{array}$}} & \multicolumn{2}{|l|}{100} & \multicolumn{2}{|l|}{0.3} & \multirow[t]{3}{*}{0.274} \\
\hline & & & 5.0 & & 0.41 & & \\
\hline & & & 10.0 & & 2.0 & & \\
\hline \multicolumn{8}{|l|}{ Glazing type } \\
\hline \multirow[t]{2}{*}{ Glazing } & \multicolumn{2}{|l|}{ Type of } & $\begin{array}{l}\text { Solar } \\
\quad \text { reflectance }\end{array}$ & $\begin{array}{l}\text { Solar } \\
\quad \text { absorptance }\end{array}$ & $\begin{array}{l}\text { Solar } \\
\quad \text { transmittance }\end{array}$ & Emissivity & $\begin{array}{l}\text { Total } \mathrm{U} \\
\quad \text { value }\left(\mathrm{W} / \mathrm{m}^{2} \cdot \mathrm{K}\right)\end{array}$ \\
\hline & Single & 10.00 & 0.070 & 0.115 & 0.7 & 0.845 & 5.53 \\
\hline
\end{tabular}

northwest facing classroom (Figure 8). Also, applying thermal insulation to the outer surface of an external wall would require protection from the outdoor environment, and this would increase the cost of construction.

In terms of solar radiation penetration through the glazing assembly, minimising WWR is an effective passive approach to reduce the amount of cooling load sharply (Figure 11). WWR would decrease the maximum load by more than $100 \%$ for the southwest facing classroom in summer from just $2000 \mathrm{~W}$ up to $4500 \mathrm{~W}$ with 90\% WWR (Figure 11(c)). This shows that reduction in WWR is an effective method to control access of solar radiation in hot and dry regions. The indoor air temperature was an important indicator of how the indoor environment could provide thermal comfort ${ }^{41}$ as well as determining energy loads based on the same. The analysis and discussion suggested that the combination of all building modifications and application was an effective method to improve the thermal and energy performance of existing buildings in hot and dry regions. The combination model was even below the thermal comfort zone ${ }^{3}$ in a study performed in Saudi Arabia in which the thermal comfort zone was designed and developed with a reference to a hot and humid climate in Saudi Arabia. As a passive technique, 


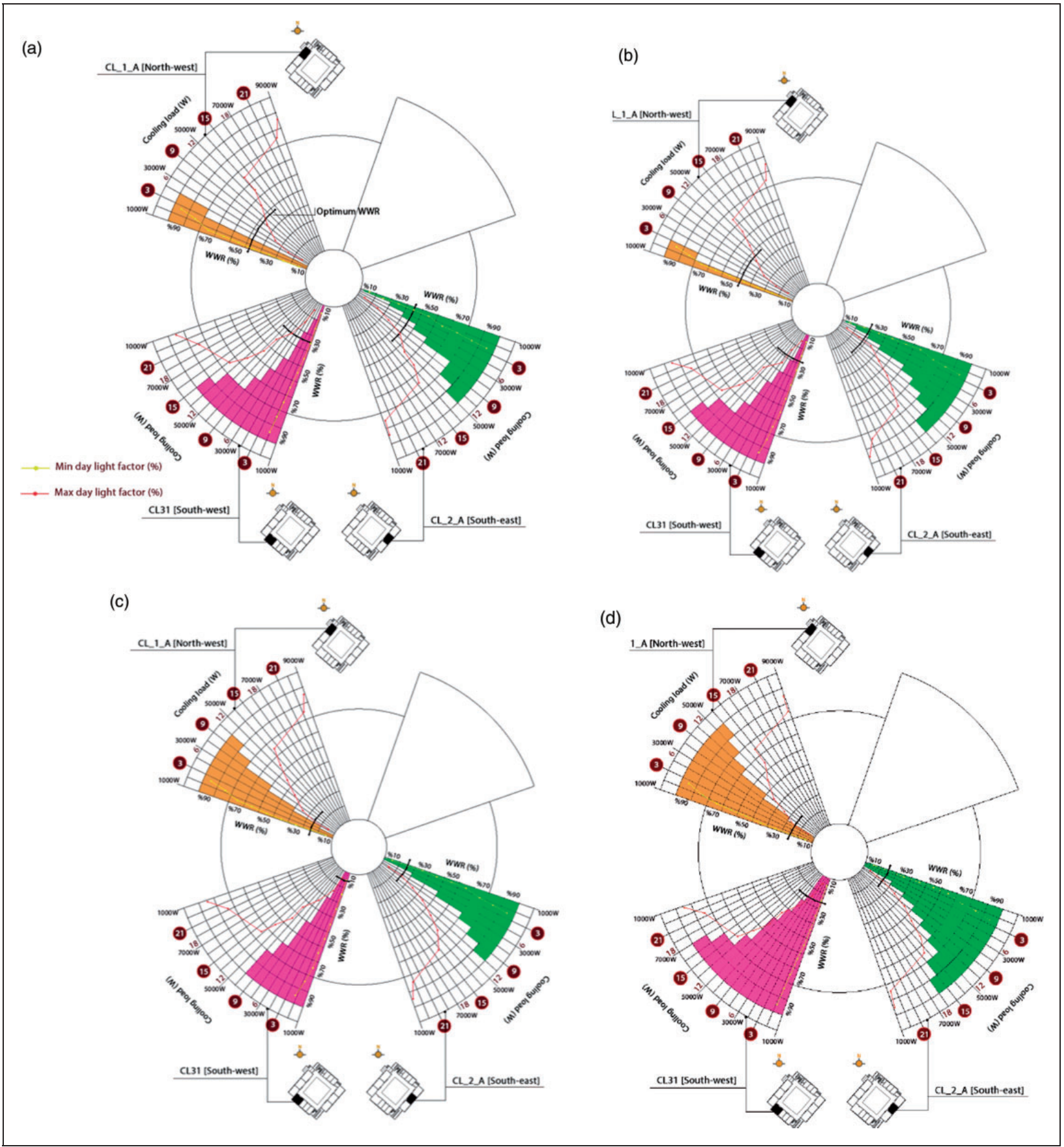

Figure 11. Peaks of cooling loads in the selected classrooms of insulated design of the school with various orientations and seasons: (a) winter, (b) spring, (c) summer and (d) autumn, with WWR ranging from $10 \%$ to $90 \%$, results obtained from TAS EDSL and TAS daylight analysis.

thermal insulation significantly impacts indoor air temperature in winter and summer. Additionally, the combination of adding thermal insulation applied to external wall as well as minimising the WWR could provide the ultimate strategy to control both indoor temperatures with an amount of solar radiation that exhibits a strong correlation with solar glare comfort.
Figure 12 presents the maximum WWR with respect to various orientations. The figure was derived by presenting maximum and minimum levels of solar gain, indoor air temperatures, accessed sunlight and heat flux which are all calculated from TAS EDSL and TAS daylight analysis. The major concern with respect to energy consumption in this region is the cooling 


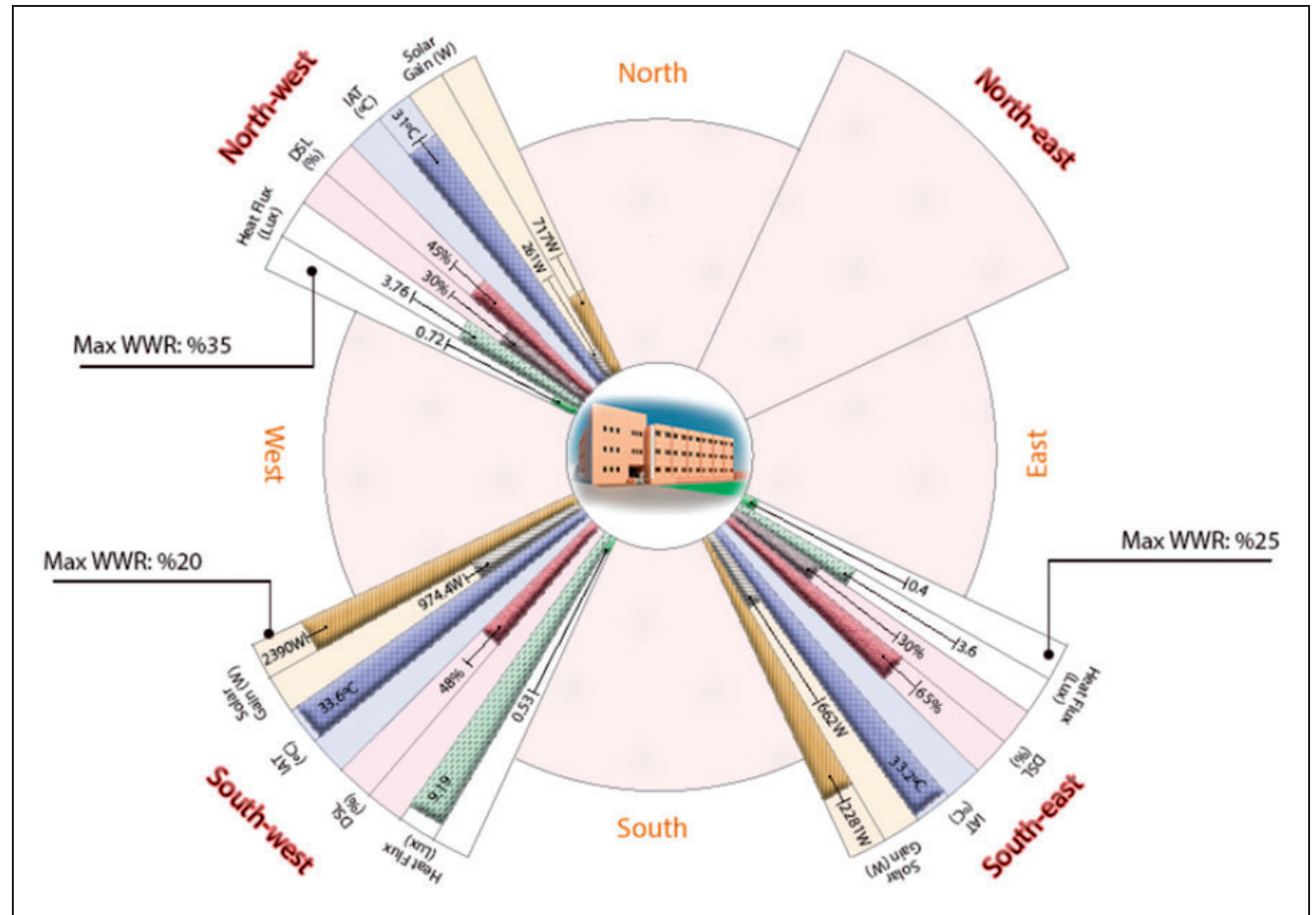

Figure 12. Framework plotting of a suitable window-to-wall ratios for various orientations.

Table 4. Tabulated findings and summary of the framework.

\begin{tabular}{|c|c|c|c|}
\hline Techniques & Recommendations & Design & Notes/comments \\
\hline $\begin{array}{l}\text { Thermal } \\
\text { insulation }\end{array}$ & $\begin{array}{l}\text { Thermal insulation should be } \\
\text { applied to the outer surface of } \\
\text { external walls and especially in } \\
\text { southern associated facing } \\
\text { classrooms including south, } \\
\text { southwest, and southeast. } \\
\text { Northern facings are left as they } \\
\text { involve minimising the cost of } \\
\text { modification }\end{array}$ & $\begin{array}{l}\text { - } 5-10 \mathrm{~cm} \text { of thermal } \\
\text { insulation to be } \\
\text { applied on the outer } \\
\text { surface of exter- } \\
\text { nal walls } \\
\text { - Thermal conductivity } \\
\text { is recommended as } \\
0.050 \text { and lower } \\
\mathrm{W} / \mathrm{mK}\end{array}$ & $\begin{array}{l}\text { Combination of applying thermal } \\
\text { insulation with controlling } \\
\text { WWR is the most appropriate } \\
\text { technique in existing buildings }\end{array}$ \\
\hline $\begin{array}{l}\text { Window-to- } \\
\text { wall ratio }\end{array}$ & $\begin{array}{l}\text { 1. Northwest facing should not } \\
\text { exceed } 35 \% \\
\text { 2. Southwest facing should } \\
\text { exceed } 20 \% \\
\text { 3. Southeast facing should not } \\
\text { exceed } 25 \%\end{array}$ & - & $\begin{array}{l}\text { Is the most effective approach in } \\
\text { conjunction with the applica- } \\
\text { tion of thermal insulation }\end{array}$ \\
\hline $\begin{array}{l}\text { Combination of } \\
\text { two strategies }\end{array}$ & $\begin{array}{l}\text { It was observed as the most effec- } \\
\text { tive as all strategies } \\
\text { were applied }\end{array}$ & - & $\begin{array}{l}\text { Thermal comfort zone in winter } \\
\text { was below comfort zone } \mathrm{e}^{3}\end{array}$ \\
\hline
\end{tabular}

since there is no heating demand even in winter. Thus, Figure 11 shows the maximum value of cooling loads in each season along with minimum and maximum values of daylight factor. According to CIBSE guide, ${ }^{42}$ the daylight factor should not be less than $2 \%$ and should not exceed 5\% inside a room for normal activities without relying on artificial light. As noted, each season has a preferable WWR which was indicated by the curves in back colour (Figure 11). The criterion is to maintain adequate daylight to minimise the maximum cooling load. For instance, for northwest facing room, $35 \%$ of WWR is recommended. This is due to the overall recommended ratio derived from the same figure. Although in winter and summer WWR can be as high 
as nearly $50 \%$, which has to be minimised due to summer and autumn recommended ratio which should not exceeds $20 \%$. This recommended WWR is based on preferable maximum values of WWR. However, it can be lower than this.

Based on previous findings and discussions and the peak of cooling load with various WWR, as shown in Figure 11 combined with maximum and minimum values of daylight factors, the northwest facing rooms would exhibit higher WWR requirement (not exceeding $35 \%$ ) while the southwest room was observed to exhibit the lowest WWR not exceeding 20\%. These findings are more detailed and descriptive than the recommendations $^{24}$ wherein an outline of the WWR was presented by considering suggested WWR in various climatic regions. However, both results are compatible and consistent. This can be seen in the correlation between cooling loads presented in Figure 11 and all elements presented in Figure 12, including solar gain and indoor air temperatures. As a result, an overview of both figures is presented in Table 4, indicating general recommendations, design and comments.

\section{Conclusions}

The study investigated several techniques including building envelope, WWR and orientation to provide a framework for prototype school building design in Saudi Arabia with respect to hot and dry climates. The study used different software to provide detailed sunlight reflection including AutoCAD, Revit and TAS EDSL. Furthermore, on-site observations were also conducted relative to the feasibility and data collections. Another method was also used, namely thermal imaging camera to examine the impact of orientation and WWR on internal glazing temperature distributions. As the building is part of the prototype school design in Saudi Arabia, the study proposed implementations for existing school buildings, and thus all suggested modifications will be potentially applied even after completion of building construction. With respect to the impact of orientation, the results indicate that orientation could significantly affect thermal performance especially in southern associated facing rooms, such as south, southwest and southeast. Thus, it is suggested that WWR of classrooms facing southwest and southeast should not exceed $20 \%$ and $25 \%$, respectively. Conversely, northwest facing classrooms can have WWR up to $35 \%$, due to significantly lower direct solar gain. One of the most important findings of the study is that WWR is an effective approach in passive design that can be applied to existing buildings and especially in hot regions. In order to maximise the effectiveness of WWR, a thermal insulation of the order of 5-10 $\mathrm{cm}$ should be applied to the outer surface of an existing building. However, this will require protection of insulation from the outdoor environment with an increased cost of construction.

\section{Authors' contribution}

MA was responsible for data collection, analysis and preparation of the paper. He alse-was responsible for writing

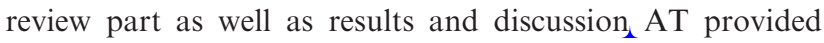
advice and contribution on the research methodology and the design of inclusive research.

\section{Acknowledgement}

The authors thank the Ministry of Education, Saudi Arabia, for allowing the research team to visit the school and conduct the study. They also thank the Head of the School who was very supportive of the research team's activities involving measurements, surveys and visits. The authors acknowledge the contribution of the research team members involved in the study as research assistants, namely $\mathrm{M}$ Othman, S Alzahrani, A Aljumaie, R Shujaa, M Albujami, A Yaseen and A Halawani. They also thank Taif University for approving and supporting academic visits to and research communication with De Montfort University, UK. Finally, the authors would like to thank the Leicester School of Architecture at De Montfort University for their valuable research collaboration.

\section{Declaration of conflicting interests}

The author(s) declare no potential conflicts of interest with respect to the research, authorship, and/or publication of this paper.

\section{Funding}

The author(s) received no financial support for the research, authorship, and/or publication of this paper.

\section{ORCID iD}

Mamdooh Alwetaishi (D) hiip://orcid.org/0000-00015053-4324

\section{References}

1. Prince Mohammed bin Salman. Our vision: Saudi Arabia. The heart of the Arab and Islamic worlds, the investment powerhouse, and the hub connecting three continents. Saudi vision, hiip://vision2030.gov.sa/en/ foreword (2016, accessed 5 March 2018).

2. Alwetaishi M and Balabel A. Numerical study of microclimatically responsive school building design in Saudi Arabia. J King Saud Univ - Eng Sci 2017; DOI:10.1016/j.jksues.2017.03.005.

3. Alwetaishi MSS Human Thermal Comfort and Building Performance of Schools in Hot and Humid Climate with a Particular Reference to Saudi Arabia, Jeddah; [PhD Thesis]; Nottingham University. Nottingham; 2015. 
4. Freire RZ, Mazuroski W, Abadie MO and Mendes N. Capacitive effect on the heat transfer through building glazing systems. Appl Energy 2011; 88: 4310-4319.

5. Lollini R, Barozzi B, Fasano G, Meroni I and Zinzi M. Optimisation of opaque components of the building envelope. Energy, economic and environmental issues. Build Environ 2006; 41: 1001-1013.

6. Kolaitis DI, Malliotakis E, Kontogeorgos DA, Mandilaras I, Katsourinis DI and Founti MA. Comparative assessment of internal and external thermal insulation systems for energy efficient retrofitting of residential buildings. Energy Build 2013; 64: 123-131.

7. Binici H, Eken M, Dolaz M, Aksogan O and Kara M. An environmentally friendly thermal insulation material from sunflower stalk, textile waste and stubble fibres. Constr Build Mater 2014; 51: 24-33.

8. Yu J, Yang C, Tian L and Liao D. A study on optimum insulation thicknesses of external walls in hot summer and cold winter zone of China. Appl Energy 2009; 86: $2520-2529$.

9. Dimoudi A and Kostarela P. Energy monitoring and conservation potential in school buildings in the $\mathrm{C}^{\prime}$ climatic zone of Greece. Renew Energy 2009; 34: 289-296.

10. Çomakli K and Yüksel B. Environmental impact of thermal insulation thickness in buildings. Appl Therm Eng 2004; 24: 933-940.

11. Mahlia TMI and Iqbal A. Cost benefits analysis and emission reductions of optimum thickness and air gaps for selected insulation materials for building walls in Maldives. Energy 2010; 35: 2242-2250.

12. Kaynakli O. A review of the economical and optimum thermal insulation thickness for building applications. Renew Sustain Energy Rev 2012; 16: 415-425.

13. Bojic M, Yik F and Sat P. Influence of thermal insulation position in building envelope on the space cooling of high-rise residential buildings in Hong Kong. Energy Build 2001; 33: 569-581.

14. Ozel M. Determination of optimum insulation thickness based on cooling transmission load for building walls in a hot climate. Energy Convers Manag 2013; 66: 106-114.

15. El-din MMS. On the heat flow into the ground. Renew Energy 1999; 18: 473-490.

16. Saleh M. Impact of thermal insulation location on buildings in hot dry climates. Sol Wind Technol 1990; 7: 393-406.

17. Zhang L, Luo T, Meng X, Wang Y, Hou C and Long E. Effect of the thermal insulation layer location on wall dynamic thermal response rate under the airconditioning intermittent operation. Case Stud Therm Eng 2017; 10: 79-85.

18. Hou C, Meng X, Gao Y, Mao W and Long E. Effect of the insulation materials filling on the thermal performance of sintered hollow bricks under the airconditioning intermittent operation. Case Stud Constr Mater 2018; 8: 217-225.

19. Alwetaishi M. Impact of glazing to wall ratio in various climatic regions: a case study. J King Saud Univ Eng Sci 2019; 31: 6-18.

20. Alghoul SK, Rijabo HG and Mashena ME. Energy consumption in buildings: a correlation for the influence of window to wall ratio and window orientation in Tripoli, Libya. J Build Eng 2017; 11: 82-86.

21. Su X and Zhang X. Environmental performance optimization of window-wall ratio for different window type in hot summer and cold winter zone in China based on life cycle assessment. Energy Build 2010; 42: 198-202.

22. Marino C, Nucara A and Pietrafesa M. Does window-towall ratio have a significant effect on the energy consumption of buildings? A parametric analysis in Italian climate conditions. J Build Eng 2017; 13: 169-183.

23. Feng G, Chi D, Xu X, Dou B, Sun Y and Fu Y. Study on the influence of window-wall ratio on the energy consumption of nearly zero energy buildings. Procedia Eng 2017; 205: 730-737.

24. Alwetaishi M. Impact of glazing to wall ratio in various climatic regions: a case study. J King Saud Univ Eng Sci 2019; 31: 6-18.

25. Priyadarsini R, Hien $\mathrm{WN}$ and Wai David CK. Microclimatic modeling of the urban thermal environment of Singapore to mitigate urban heat island. Sol Energy 2008; 82: 727-745.

26. Berger $\mathrm{T}$, Amann $\mathrm{C}$, Formayer $\mathrm{H}$, et al. Impacts of external insulation and reduced internal heat loads upon energy demand of offices in the context of climate change in Vienna, Austria. J Build Eng 2016; 5: 86-95.

27. Resuli P and Dervishi S. Thermal performance of cultural heritage Italian housing in Albania. Energy Procedia 2015; 78: 753-758.

28. Carlini M, Zilli D and Allegrini E. Simulating building thermal behaviour: the case study of the School of the State Forestry Corp. Energy Procedia 2015; 81: 55-63.

29. Pino A, Bustamante W, Escobar R and Pino FE. Thermal and lighting behavior of office buildings in Santiago of Chile. Energy Build 2012; 47: 441-449.

30. Dudkiewicz E and Fidorow-Kaprawy N. The energy analysis of a hybrid hot tap water preparation system based on renewable and waste sources. Energy 2017; 127: 198-208.

31. Kendrick C, Ogden R, Wang X and Baiche B. Thermal mass in new build UK housing: A comparison of structural systems in a future weather scenario. Energy Build 2012; 48: 40-49.

32. Zoras S, Veranoudis S and Dimoudi A. Micro-climate adaptation of whole building energy simulation in large complexes. Energy Build 2017; 150: 81-89.

33. Gucyeter B. Evaluating diverse patterns of occupant behavior regarding control-based activities in energy performance simulation. Front Archit Res 2018; 7: 167-179.

34. Meteonorm, hiips://meteonorm.com/ (2017, accessed 6 May 2017).

35. Alwetaishi M, Gadi M and Issa UH. Reliance of building energy in various climatic regions using multi criteria. Int $J$ Sustain Built Environ 2017; 6: 555-564.

36. Saleh PH. Thermal performance of glazed balconies within heavy weight/thermal mass buildings in Beirut, Lebanon's hot climate. Energy Build 2015; 108: 291-303.

37. Al-Sanea SA and Zedan MF. Improving thermal performance of building walls by optimizing insulation layer 
distribution and thickness for same thermal mass. Appl Energy 2011; 88: 3113-3124.

38. Al-Turki A and Zaki GM. Cooling load response for building walls comprising heat storing and thermal insulating layers. Energy Convers Manag 1991; 32: 235-247.

39. Meng X, Huang Y, Cao Y, et al. Optimization of the wall thermal insulation characteristics based on the intermittent heating operation. Case Stud Constr Mater 2018; 9: e00188.
40. Kossecka E and Kosny J. Influence of insulation configuration on heating and cooling loads in a continuously used building. Energy Build 2002; 34: 321-331.

41. Alwetaishi MS. Impact of building function on thermal comfort: a review paper. Am J Eng Appl Sci 2016; 9: 928-945.

42. CIBSE. Natural ventilation in non-domestic building. London: The Chartered Institution of Building Services Engineers (CIBSE), 1997. 